\title{
Undergraduate Students' Readiness In E-Learning : A Study At The Business School in a Malaysian Private University
}

\author{
Siew Fun Tang, Chee Leong Lim \\ Taylor's Business School, and Teaching and Educational Development, \\ Taylor's University, No 1, Jalan Taylor's, 47500 Subang Jaya, Selangor Darul Ehsan, Malaysia. \\ siewfun.tang@taylors.eud.my \\ E-Learning Academy, Taylor's University, \\ No. 1, Jalan Taylor's, 47500 Subang Jaya, Selangor Darul Ehsan, Malaysia. \\ cheeleong.lim@taylors.edu.my

\begin{abstract}
This study investigated the factor structure of readiness constructs as expressed by undergraduate students and examined how these constructs correlated with some selected socio-demographic characteristics at the Business School of a Malaysian private university. Results were based on responses from 172 undergraduate students who were exposed to some kind of e-learning activities. The 13-item questionnaire used was adapted from The Readiness for Online Learning Survey by McVay (2001). Exploratory Factor Analysis yielded four aspects of motivation that described themes of self-study management, reflective thinking, interaction support and learning setting. The similarities and differences between this study and past researches were discussed.
\end{abstract}

\section{Keywords}

Student readiness, e-learning, private higher education, self directed learning

\section{Academic Discipline And Sub-Disciplines}

Management, Information Technology

\section{SUBJECT CLASSIFICATION}

e-learning

\section{TYPE (METHOD/APPROACH)}

Quantitative Research Method; Questionnaire; Exploratory Factor Analysis.

\section{Council for Innovative Research}

Peer Review Research Publishing System

Journal: International Journal of Management \& Information Technology

Vol.4, No.2

editor@cirworld.com

www.cirworld.com, member.cirworld.com 


\section{INTRODUCTION}

Making effective use of technology in delivering the curriculum has begun to take importance in many universities especially in the university understudy which is a Malaysian private university in response to the enrollment demands (Kim \& Bonk, 2006). The principal business drivers for embracing e-learning include enhancing the quality of the student learning experience, facilitating leading, practice and innovative approaches to learning and teaching, providing flexibility of provision to support a diverse student population, and enriching the campus experience for students. However, integrating technology into any curriculum cannot be adopted overnight but a long journey that is required to adapt ever so often to cope with changes in technology.

Readiness for e-learning refers to three major aspects namely (1) students' preferences for online learning as opposed to face-to-face learning instructions, (2) students' capability and confidence in using the technologies tools, and (3) students' ability to learn independently (Warner, et al, 1998). Smith (2000) found that students' learning preferences could be influenced by the comfort with learning sequences and engagement with independent learning. This concurs with findings by Riding and Cheema (1991) and Dadler-Smith and Riding (1999).

Since e-learning is rather a new driving force behind a new learning experience which will give the institution understudy an advantage and competitive edge over other local higher learning institutions, almost all of which have yet to consciously embark on this path. When shifting into e-learning, the unique learning style of cohorts of students and the nature of the content must be considered. Therefore, it is timely for the authors to assess whether the students are ready for this new learning format and identify the important factors that affect students' readiness in order to ensure the successful implementation of e-learning in the business school understudy which has embarked on the foundational phase of the transformation process.

\section{METHODOLOGY}

172 undergraduate business studies students from four different study modules (courses) in the business school of a Malaysian private university participated voluntarily in this study. They exposed to some kind of e-learning activities in their courses as stated in Table 1.

Table 1. e-Learning activities experienced by the participants

\begin{tabular}{|c|c|c|}
\hline Level & Course & e-Learning Initiatives \\
\hline \multirow[t]{3}{*}{ Degree } & $\begin{array}{l}\text { MIS } \\
\text { Management } \\
\text { Information System } \\
\text { (BUS 1704) }\end{array}$ & $\begin{array}{l}\text { Digital Dropbox for online assignment submission, Online forum for discussion } \\
\text { of assignments and tutorial questions, Online Quizzes and Exercises, Online } \\
\text { consultation using Skype, Uploading videos from Youtube or any Internet } \\
\text { sources, Google sites for e-portfolio, Video/Multimedia assignment, Google } \\
\text { Docs for collaboration and discussion }\end{array}$ \\
\hline & $\begin{array}{l}\text { OB } \\
\text { Organisational } \\
\text { Behaviour (BUS1524) }\end{array}$ & $\begin{array}{l}\text { Safe Assign for plagiarism detection, Digital Dropbox for online assignment } \\
\text { submission, Online forum for discussion of assignments and tutorial questions } \\
\text { in Facebook, Online quizzes and exercises. A one-week e-learning week was } \\
\text { implemented in week } 10 \text {. }\end{array}$ \\
\hline & $\begin{array}{l}\text { EPM } \\
\text { Export Practice and } \\
\text { Management (BUS } \\
2524 \text { ) }\end{array}$ & $\begin{array}{l}\text { Safe Assign for plagiarism detection, Digital Dropbox for online assignment } \\
\text { submission, Online forum for discussion of assignments and tutorial questions, } \\
\text { Online quizzes and exercises, and online discussion in Facebook }\end{array}$ \\
\hline Diploma & $\begin{array}{l}\text { PM } \\
\text { Principles of } \\
\text { Management } \\
\text { (MGTD102) }\end{array}$ & $\begin{array}{l}2 \text { hours face to face (lecture) per week with the remaining } 2 \text { hours online } \\
\text { learning (tutorial) i.e. } 50 \% \text { blended learning. Used BB7 and GoogleDoc for } \\
\text { document upload, discussion forum in BB7/Facebook, and video clips from } \\
\text { YouTube. }\end{array}$ \\
\hline
\end{tabular}

The participants' age mostly ranged from $18-25$ years old with $89.5 \%$ of the participants are local students and $58.1 \%$ are males. Permissions were obtained from the lecturers for administering the questionnaire during their tutorial classes. The participants were briefed on the purpose of the study and told of their rights to withhold their participation during or after they had completed the questionnaire. A 13-item questionnaire, adapted from The Readiness for Online Learning Survey by McVay (2001) was used in this study. Each item was measured on a four-point Likert scale with $1=$ Strongly disagree to 4 = Strongly agree. The participants were also asked to report their year of birth, gender, gender, nationality, study major, study level, year at the university and the study programme that they first enrolled at the university. They were assured of the confidentiality of their responses which would be used for research and would not be used in any way to refer to them as an individual.

\section{RESEARCH FINDINGS}

An exploratory factor analysis (EFA) was performed to reduce the large number of variables (items) to a smaller set of underlying factors that summarise the essential information contained in the variables. It is used because the researchers 
did not have strong theory about the constructs underlying responses to their measures. The detailed explanation of the analysis and its interpretation are presented below.

The Barlett's test of spherity was significant and Kaiser-Meyer-Olkin (KMO) measure of sampling adequacy was 0.679 , greater than 0.6. An inspection of the anti-image correlation matrix (Table 2) that all the measures of sampling adequacy is well above the acceptable level of 0.5 . A factor loading criterion of 0.40 was adopted for inclusion of an item in the results interpretation, more stringent than the usual 0.3 .

Table 2. Anti-image Matrices

\begin{tabular}{|c|c|c|c|c|c|c|c|c|c|c|c|c|c|c|}
\hline & & $\mathrm{R} 1$ & $\mathrm{R} 2$ & R3 & R4 & R5 & $\mathrm{R} 6$ & R7 & $\mathrm{R} 8$ & R9 & $\mathrm{R} 10$ & R11 & R12 & $\mathrm{R} 13$ \\
\hline \multirow{13}{*}{$\begin{array}{l}\text { Anti-image } \\
\text { Covariance }\end{array}$} & $\mathrm{R} 1$ & .761 & -.236 & -.010 & .082 & .036 & .026 & -.167 & .023 & -.096 & .006 & -.024 & .090 & -.069 \\
\hline & $\mathrm{R} 2$ & -.236 & .561 & -.245 & -.010 & -.028 & -.125 & .184 & .071 & .024 & .041 & -.129 & -.089 & .028 \\
\hline & R3 & -.010 & -.245 & .593 & -.117 & -.247 & .050 & -.033 & -.121 & -.017 & .000 & .042 & .000 & .030 \\
\hline & R4 & .082 & -.010 & -.117 & .836 & .048 & .060 & -.060 & -.042 & -.121 & -.021 & -.028 & -.036 & -.108 \\
\hline & $\mathrm{R} 5$ & .036 & -.028 & -.247 & .048 & .766 & -.042 & -.101 & .037 & -.007 & -.058 & .055 & -.038 & .083 \\
\hline & $\mathrm{R6}$ & .026 & -.125 & .050 & .060 & -.042 & .790 & -.170 & -.013 & -.220 & -.071 & .092 & -.004 & -.060 \\
\hline & R7 & -.167 & .184 & -.033 & -.060 & -.101 & -.170 & .745 & -.025 & -.046 & .032 & -.053 & -.133 & -.071 \\
\hline & R8 & .023 & .071 & -.121 & -.042 & .037 & -.013 & -.025 & .702 & -.056 & -.148 & -.040 & -.027 & -.137 \\
\hline & $\mathrm{R9}$ & -.096 & .024 & -.017 & -.121 & -.007 & -.220 & -.046 & -.056 & .800 & -.023 & -.007 & -.011 & -.028 \\
\hline & $\mathrm{R} 10$ & .006 & .041 & .000 & -.021 & -.058 & -.071 & .032 & -.148 & -.023 & .545 & -.277 & -.011 & -.042 \\
\hline & $\mathrm{R} 11$ & -.024 & -.129 & .042 & -.028 & .055 & .092 & -.053 & -.040 & -.007 & -.277 & .527 & -.034 & -.104 \\
\hline & R12 & .090 & -.089 & .000 & -.036 & -.038 & -.004 & -.133 & -.027 & -.011 & -.011 & -.034 & .840 & -.137 \\
\hline & R13 & -.069 & .028 & .030 & -.108 & .083 & -.060 & -.071 & -.137 & -.028 & -.042 & -.104 & -.137 & .663 \\
\hline \multirow{13}{*}{$\begin{array}{l}\text { Anti-image } \\
\text { Correlation }\end{array}$} & R1 & $.588^{\mathrm{a}}$ & -.361 & -.015 & .103 & .048 & .034 & -.222 & .032 & -.123 & .009 & -.038 & .113 & -.097 \\
\hline & $\overline{\mathrm{R} 2}$ & -.361 & $.516^{a}$ & -.425 & -.014 & -.043 & -.187 & .285 & .113 & .036 & .074 & -.236 & -.129 & .046 \\
\hline & R3 & -.015 & -.425 & $.595^{a}$ & -.166 & -.367 & .073 & -.050 & -.187 & -.025 & -.001 & .075 & .000 & .048 \\
\hline & $\mathrm{R} 4$ & .103 & -.014 & -.166 & $.775^{a}$ & .060 & .074 & -.076 & -.054 & -.148 & -.031 & -.043 & -.043 & -.145 \\
\hline & R5 & .048 & -.043 & -.367 & .060 & $.590^{\mathrm{a}}$ & -.053 & -.134 & .050 & $\begin{array}{l}.009 \\
\end{array}$ & -.089 & .087 & -.047 & .116 \\
\hline & R6 & .034 & -.187 & .073 & .074 & -.053 & $.604^{a}$ & -.221 & -.018 & -.276 & -.108 & .142 & -.004 & -.083 \\
\hline & R7 & -.222 & .285 & -.050 & -.076 & -.134 & -.221 & $.618^{a}$ & -.035 & -.060 & .050 & -.084 & -.168 & -.101 \\
\hline & $\mathrm{R} 8$ & .032 & .113 & -.187 & -.054 & .050 & -.018 & -.035 & $.804^{a}$ & -.075 & -.239 & -.065 & -.035 & -.201 \\
\hline & R9 & -.123 & .036 & -.025 & -.148 & -.009 & -.276 & -.060 & -.075 & $.773^{\mathrm{a}}$ & -.035 & -.011 & -.013 & -.039 \\
\hline & R10 & .009 & .074 & -.001 & -.031 & -.089 & -.108 & .050 & -.239 & -.035 & $.711^{\mathrm{a}}$ & -.518 & -.016 & -.070 \\
\hline & R11 & -.038 & -.236 & .075 & -.043 & .087 & .142 & -.084 & -.065 & -.011 & -.518 & $.688^{\mathrm{a}}$ & -.051 & -.177 \\
\hline & R12 & .113 & -.129 & .000 & -.043 & -.047 & -.004 & -.168 & -.035 & -.013 & -.016 & -.051 & $.785^{\mathrm{a}}$ & -.183 \\
\hline & $\bar{R} 13$ & -.097 & .046 & .048 & -.145 & .116 & -.083 & -.101 & -.201 & -.039 & -.070 & -.177 & -.183 & $.818^{a}$ \\
\hline
\end{tabular}

Table 3. Communalities

\begin{tabular}{|c|c|c|}
\hline 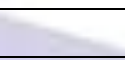 & Initial & Extraction \\
\hline $\mathrm{R} 1$ & 1.000 & .688 \\
\hline R2 & 1.000 & .755 \\
\hline R3 & 1.000 & .744 \\
\hline R4 & 1.000 & .356 \\
\hline R5 & 1.000 & .632 \\
\hline R6 & 1.000 & .562 \\
\hline R7 & 1.000 & .534 \\
\hline R8 & 1.000 & .489 \\
\hline $\mathrm{R} 9$ & 1.000 & .462 \\
\hline R10 & 1.000 & .607 \\
\hline R11 & 1.000 & .705 \\
\hline R12 & 1.000 & .291 \\
\hline R13 & 1.000 & .547 \\
\hline
\end{tabular}

The communalities of the items shown in Table 3 range from 0.291 to 0.755 are acceptable. A communality represents the variance in that variable accounted for by all the factors and is calculated by summing the squared of all factor loadings for 
a variable. Low communality indicates that the factor model is not effective and the variable should be omitted from the model. On the other hand, low communalities across the set of variables indicate that the variables are weakly related to each other. Usually a communality of 0.75 is considered high and a communality of 0.25 is considered low. However, it is vital that communalities are construed with the interpretability of the factors. For example, it is pointless if the factor on which the variable is loaded is not interpretable or not contributing to a well-defined factor even though the communality is high, though it usually will not be and vice-versa. A communality value greater than one signals a spurious solution due to insufficient sample size or the number of factors is either too big or too small.

Table 4. Total Variance Explained

\begin{tabular}{|c|c|c|c|c|c|c|c|c|c|}
\hline \multirow[b]{2}{*}{ Component } & \multicolumn{3}{|c|}{ Initial Eigenvalues } & \multicolumn{3}{|c|}{ Extraction Sums of Squared Loadings } & \multicolumn{3}{|c|}{ Rotation Sums of Squared Loadings } \\
\hline & Total & $\begin{array}{r}\% \text { of } \\
\text { Variance }\end{array}$ & $\begin{array}{r}\text { Cumulative } \\
\%\end{array}$ & Total & $\begin{array}{r}\% \text { of } \\
\text { Variance }\end{array}$ & Cumulative \% & Total & $\%$ of Variance & Cumulative \% \\
\hline 1 & 3.109 & 23.915 & 23.915 & 3.109 & 23.915 & 23.915 & 2.580 & 19.843 & 19.843 \\
\hline 2 & 1.823 & 14.020 & 37.936 & 1.823 & 14.020 & 37.936 & 1.678 & 12.904 & 32.748 \\
\hline 3 & 1.317 & 10.132 & 48.068 & 1.317 & 10.132 & 48.068 & 1.631 & 12.549 & 45.296 \\
\hline 4 & 1.123 & 8.635 & 56.702 & 1.123 & 8.635 & 56.702 & 1.483 & 11.406 & 56.702 \\
\hline 5 & .919 & 7.068 & 63.771 & & & & & & \\
\hline 6 & .905 & 6.961 & 70.732 & & & & & & \\
\hline 7 & .812 & 6.247 & 76.978 & & & & & & \\
\hline 8 & .676 & 5.200 & 82.178 & & & & & & \\
\hline 9 & .635 & 4.883 & 87.061 & & & & & & \\
\hline 10 & .540 & 4.155 & 91.217 & & & & & & \\
\hline 11 & .468 & 3.600 & 94.816 & & & & & 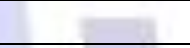 & \\
\hline 12 & .373 & 2.871 & 97.687 & & & & & & \\
\hline 13 & .301 & 2.313 & 100.000 & 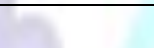 & & & & & \\
\hline
\end{tabular}

The total variance was explained at three stages as illustrated in Table 4. At the initial stage, it shows the factors and their associated eigen values, the percentage of variance explained and the cumulative percentages. An eigen value for a factor is calculated by totalling the squared factor loadings for all the variables and it gauges the variance in all the variables which is accounted for by that factor. Note that the eigen value is not the percent of variance explained but rather a measure of the amount of variance in relation to total variance since variables are standardized to have means of 0 and variances of 1 with total variance being equal to the number of variables. A factor with a low eigen value (less than one) is usually removed from the model because it does not contribute significantly to the explained variances in the variables. In this, 13 factors would be needed to explain $100 \%$ of the variance in the data. With reference to the eigen values, four factors were expected to be extracted because they have big eigenvalues ranging from approximately 1.123 to 3.109 . If four components were extracted, then $56.702 \%$ of the variance would be explained.

The scree plot in Figure 1 graphically displays the eigen values for each factor and suggest that there is one predominant factor. However, closer scrutiny reveals that, the first four factors contribute bigger amounts of the total variance. Thereafter, the line is almost flat, meaning that each successive component is accounting for smaller and smaller amounts of the total variance.

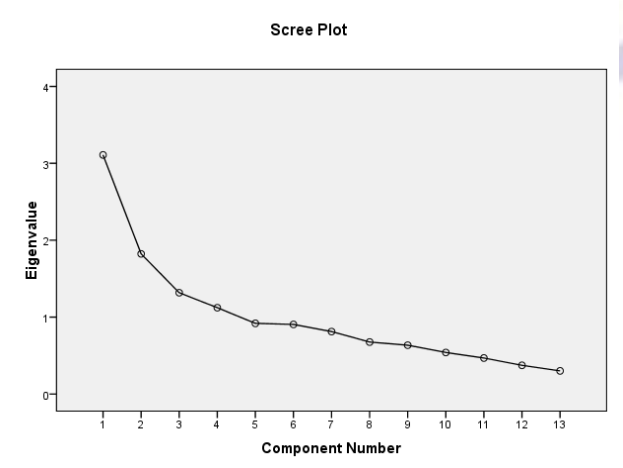

Fig 1: Scree Plot

The factor matrix shows the matrix of loadings or correlations between the variables and factors. For a given factor, the ratio of the sum of squared of all factor loadings and the number of variables gives the percentage of variance in all the variables accounted for by the factor. Pure variables have loadings of 0.4 or greater on only one factor. The factor matrix indicates that there are complex variables which have high loadings on more than one factor, and they make interpretation of the output difficult. Hence, varimax rotation is necessary here to assist in simplifying the interpretation. 
Table 5. Rotated Component Matrix ${ }^{\mathrm{a}}$

\begin{tabular}{|c|c|c|c|c|}
\hline & \multicolumn{3}{|c|}{ Component } & \\
\hline & 1 & 2 & 3 & 4 \\
\hline R11 & .766 & & & \\
\hline $\mathrm{R} 10$ & .763 & & & \\
\hline R8 & .675 & & & \\
\hline R13 & .659 & & & \\
\hline R4 & .484 & & & \\
\hline $\mathrm{R} 12$ & .421 & & & \\
\hline R6 & & .730 & & \\
\hline R7 & & .689 & & \\
\hline $\mathrm{R} 9$ & & .637 & & \\
\hline R3 & & & .803 & \\
\hline R5 & & & .779 & \\
\hline R1 & & & & .787 \\
\hline $\mathrm{R} 2$ & & & .447 & .736 \\
\hline
\end{tabular}

Varimax rotation, which requires the factor axes to be kept at right angles to each other, is the most common method used by researchers. However, one complex variable (R2) still exists in the rotated factor matrix after varimax rotation (Table 5). An attempt using promax rotation indicated a more appropriate choice (see Pattern Matrix using Promax Rotation below) .

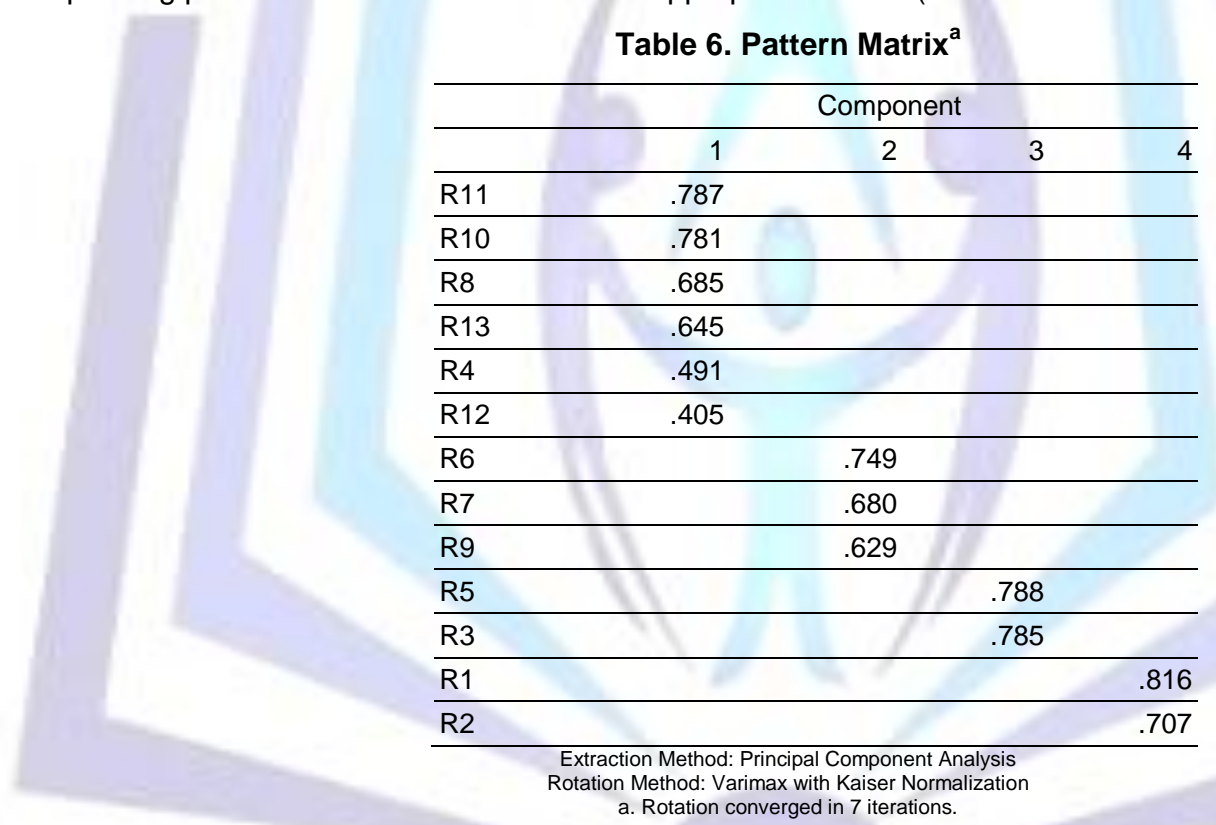

The promax rotation (see Table 6) provides a far more interpretable solution than that of the varimax rotation because the difference between high and low loadings is more apparent in the pattern matrix which eliminates the complex variables and has a simpler structure. The loadings in the pattern matrix represent that unique relationship between the factor and the variable. The factor correlation matrix as shown in Table 7 indicates that all the factors appear to be very lowly related.

Table 7. Factor Correlation Matrix

\begin{tabular}{lrrrr}
\hline Factor & 1 & 2 & 3 & 4 \\
\hline 1 & 1.000 & .260 & .084 & .160 \\
\hline 2 & .260 & 1.000 & .065 & -.025 \\
\hline 3 & .084 & .065 & 1.000 & .147 \\
\hline 4 & .160 & -.025 & .147 & 1.000 \\
\hline \multicolumn{4}{c}{$\begin{array}{c}\text { Extraction Method: Principal Component Analysis } \\
\text { Rotation Method: Varimax with Kaiser Normalization }\end{array}$} \\
\end{tabular}


Table 8. Pattern Matrix showing factor loadings for student readiness in online learning questionnaire

\begin{tabular}{|c|c|c|c|c|c|c|c|c|}
\hline & Derived & Stuc & ent Readiness in Online Learning & & & $\mathrm{Fac}$ & & \\
\hline & Factors & Lev & of agreement & & 1 & 2 & 3 & 4 \\
\hline & $\begin{array}{l}\text { Self-study } \\
\text { management }\end{array}$ & 11. & $\begin{array}{l}\text { I am able to manage my study time effectively and } \\
\text { easily complete assignments on time. }\end{array}$ & .787 & & & & \\
\hline & & 10. & $\begin{array}{l}\text { In my studies, I am a self-disciplined and find it } \\
\text { easy to set aside reading and homework time. }\end{array}$ & .781 & & & & \\
\hline 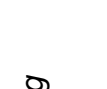 & & 8. & $\begin{array}{l}\text { When it comes to learning and studying, I am a } \\
\text { self-directed person. }\end{array}$ & .685 & & & & \\
\hline 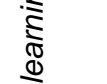 & & & $\begin{array}{l}\text { In my studies, I set goals and have a high degree } \\
\text { of initiative. }\end{array}$ & .645 & & & & \\
\hline 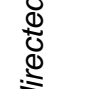 & & & $\begin{array}{l}\text { I am willing to dedicate 8-10 hours per week for my } \\
\text { studies. }\end{array}$ & & & & & \\
\hline (1) & & 12. & As a student, I enjoy working independently. & .405 & & & & \\
\hline & $\begin{array}{l}\text { Reflective } \\
\text { thinking }\end{array}$ & & $\begin{array}{l}\text { I feel that my background and experience will be } \\
\text { beneficial to my studies. }\end{array}$ & & & & & \\
\hline & & 7. & I am comfortable with written communication. & & .680 & & & \\
\hline & & 9. & $\begin{array}{l}\text { I believe looking back on what I have learned in a } \\
\text { course will help me to remember it better. }\end{array}$ & & .629 & & & \\
\hline (2) & $\begin{array}{l}\text { Interaction } \\
\text { Support }\end{array}$ & 5. & $\begin{array}{l}\text { I feel that online learning is of at least equal quality } \\
\text { to traditional classroom learning. }\end{array}$ & & & .788 & & \\
\hline 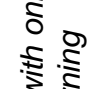 & & 3. & $\begin{array}{l}\text { I am willing to actively communicate with my } \\
\text { classmates and instructors electronically. }\end{array}$ & & & .785 & & \\
\hline है & Learning Setting & 1. & $\begin{array}{l}\text { I am able to easily access the Internet as needed } \\
\text { for my studies. }\end{array}$ & & & & .816 & \\
\hline & & & omfortable communicating electronically. & & & & .707 & \\
\hline
\end{tabular}

The results from the Exploratory Factor Analysis confirms that the four theorised dimensions emerged and they are labelled as follows:
Factor 1:
Self-study management
Factor 2: $\quad$ Reflective thinking
Factor 3: Interaction Support

Factor 4: $\quad$ Learning Setting

These four theorised dimensions will be validated by the researchers in future study using a separate data set and Confirmatory Factor Analyses.

\section{DISCUSSION AND CONCLUSION}

The purpose of this study was twofold. The first was to assess the readiness of students for e-Learning and the second was to identify the important factors that affect students' readiness in order to ensure the successful implementation of eLearning in the business school understudy. The study has found that the students were ready for e-learning and the student readiness for e-learning can be categorized into four components i.e. self-study management, reflective thinking, interaction support and learning setting. However, the authors are aware that it is also crucial to assess the readiness of instructors or faculty members in order to get a clearer picture on the overall organization's readiness in e-learning implementation. This is part of their future research study.

The major factors identified in this study that affect students; readiness in e-learning strongly concur with other research findings from the forader glexible learning literature. The two factors identified in Smith et al (2003) using the same questionnaire, namely "self-directed learning" and "confort with e-learning" are now being divided into more precise factors as illustrated in Table 8 and this is a new contribution to the body of knowledge.

The study also found that the adoption of blended learning, a combination of face-to-face and e-learning approaches has benefited the school as well as the university in many ways. This flexible approach best fits the current learning and 
teaching environment and aspirations at university, builds on and consolidates existing best practice at the university, enriches the student experience and learning outcomes through effective knowledge acquisition skills; enhances formal and informal learning opportunities, supports the important goal of accommodating student diversity, reflects international theorizing and leading practice in this area, and avoids the 'all-or-nothing' assumptions inherent in current e-learning approaches. More importantly, blended learning supports current institutional strategic directions in learning and teaching, including opportunities for promoting interdisciplinary study and research, internationalizing the curriculum, enhancement of research-teaching linkages and of work-integrated learning, and complements the existing views of flexible learning while at the same time emphasizing the unique pedagogical qualities characterizing the blending of faceto-face and technology- enhanced learning and teaching. With technological advances, e-learning allows the university to provide alternative modes of delivery of courses during times of crises which may require closure of campus facilities.

The generation of learners today is technological savvy due to the technological advances and this makes them more ready to adopt e-learning as part of learning revolution that has started to take place in higher education institutions in Malaysia as well as in the world. The university understudy uses e-learning as the primary driving force behind a new learning experience which will give the institution an advantage and competitive edge over other local higher learning institutions, almost all of which have yet to consciously embark on this path. E-learning will play a vitally important role in equipping graduates with the skills they need to succeed in the 21 st-century digital economy and the potential to revolutionize the basic tenets of learning emphasizing customized learning solutions over generic, one-size-fits-all approaches.

\section{REFERENCES}

[1] Kim, K. J. and Bonk, C. J. 2006. The future of online teaching and leanring in Higher Education. Educause Quarterly, no. 4, 22-30.

[2] McVay, M. (2001). How to e a successful distance learning student: Learning on the Internet. New Yok: Prentice Hall.

[3] Riding, R. J. and Cheema, I. 1991. Cognitive stules: An overview and integration. Educational Psychology, Vol. 11, 193-215.

[4] Sadler-Smith, E and Riding, R (1999). Cognitive stule and instructional preferences. Instructional Science, Vol. 27, 355-371.

[5] Smith, P. J. (2000). Preparedness for flexible delivery among vocational learners, Distance Education, Vol. 21, No. 1, 29-48.

[6] Smith, P. J., Murphy, K. L., and Mahoney, S. E. 2003. Towards Identifying Factors Underlying Readiness for Online Learning: An Exploratory Study. Distance Education, Vol. 24, No. 1. 57-67

[7] Warner, D., Christie, G., and Choy, S. 1998. The readiness of the VET sector for flexible delivery including on-line leanring. Brisbane: Australia National Training Authority.

\section{Author's biography with Photo}

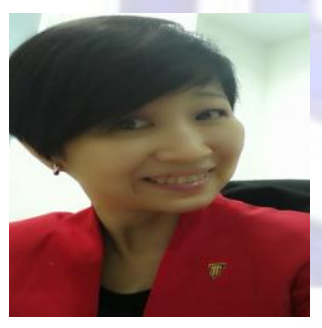

Dr. Siew Fun Tang is Head, Teaching and Educational Development and Senior Lecturer at Taylor's Business School, Taylor's University, Malaysia. She has been in the education industry for 16 years, both in teaching and administration. She specialises in quality assurance management, policy implementation academic development and teaching and learning enhancement.

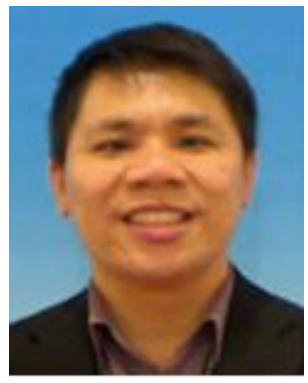

Mr Chee Leong Lim was a senior lecturer at Taylor's Business School, Taylor's University, Malaysia and now heads the e-learning Academy in the University. $\mathrm{He}$ has been in the education industry for 13 years, both in teaching and administration. He specialises in e-learning and information system management. 